\title{
A Long Term Feeding Trial of Excess Tryptophan in Laying Pullets
}

\author{
Iwao Tasaki, Koshi Asakura and Michiko Komiya \\ Laboratory of Animal Nutrition, Faculty of Agriculture, Nagoya University, Nagoya 464
}

The effect of tryptophan deficiency and excess on the laying performance of White Leghorn pullets was reported previously'). The result showed that even in a short term experiment ( 25 days) the pullets responded to the slight deficiency of tryptothan $(90 \%$ of the requirement) and laying performance (egg production rate and egg weight) reduced remarkably. On the contrary, even when the pullets received a very large dose of tryptophan (655\% of the requirement) no ill-effect on the laying performance was observed. Since the previous experiment had been conducted only for a short period, a long term feeding experiment was carried out to examine whether excess tryptophan showed any ill-effect.

\section{Materials and Methods}

A total of 24 White Leghorn pullets of 8.5 months of age, weighing about $1.7 \mathrm{~kg}$, were divided into 2 groups. All birds were carefully selected so that they had shown more than $90 \%$ of egg production rate. The birds were placed in metabolism cages and diets were provided individually. The duration of the experiment was 24 weeks, from February 3rd through July 24th. Egg production was recorded every day, feed intake was measured every week and body weight was checked every 4 weeks. One of the groups was given a commercial laying ration (CP 15.5\%) as a control and another group was provided the same diet supplemented with $0.5 \%$ L-tryptophan. The birds were allowed to eat diet and drink water ad libitum. The composition of the control diet was not informed, however, it had been proven that with this diet the birds could produce eggs normally. Amino acid composition of the control diet was measured and it was shown that all amino acids met the requirements. Since tryptophan content of the control diet was $0.16 \%$, that of the tryptophan supplemented diet was estimated to be $0.66 \%$.

Since egg albumen contains a fairy large amount of lysozyme and the lysozyme contains a remarkable amount of tryptophan, being about 10\%, eggs laid from the start to the end of the experiment were collected periodically, and albumen weight, protein and tryptophan contents of albumen were measured in order to examine the effect of excess tryptophan given to the birds.

Amino acid composition of the diet was determined by the method of BLACKBURN ${ }^{2)}$ using an ion-exchange chromatography (JEOL Model JLC-6AH) after acid hydrolysis of the samples. Tryptophan in the diet and egg albumen was determined by the method of SPIES and CHAMBERS $^{3)}$ after alkaline hydrolysis of the samples. 
Table 1. Performance of layers

\begin{tabular}{|c|c|c|c|c|c|c|c|}
\hline Week & $0-4$ & $4-8$ & $8-12$ & $12-16$ & $16-20$ & $20-24$ & $0-24$ \\
\hline \multicolumn{8}{|c|}{ Body weight gain, $\mathrm{g}$} \\
\hline Cont & 0.04 & 0.04 & 0.04 & -0.07 & 0.07 & 0.05 & 0.17 \\
\hline Trp & 0.04 & 0.03 & 0.03 & -0.07 & 0.07 & 0.03 & 0.13 \\
\hline SEM & .01 & .01 & .01 & .02 & .02 & .01 & .02 \\
\hline \multicolumn{8}{|c|}{ Number of eggs } \\
\hline Cont & 26.3 & 26.1 & 25.2 & 23.3 & 23.6 & 23.2 & 147.6 \\
\hline $\operatorname{Trp}$ & 25.9 & 25.9 & 23.6 & 22.9 & 22.4 & 24.6 & 144.8 \\
\hline SEM & .5 & .5 & .6 & .7 & .9 & .7 & 2.9 \\
\hline \multicolumn{8}{|c|}{ Egg production rate, $\%$} \\
\hline Cont & 93.8 & 93.1 & 89.9 & 83.3 & 84.2 & 82.7 & 87.9 \\
\hline $\operatorname{Trp}$ & 92.6 & 92.5 & 87.7 & 81.7 & 79.8 & 87.9 & 86.2 \\
\hline SEM & 1.7 & 1.8 & 2.1 & 2.3 & 3.1 & 2.3 & 1.8 \\
\hline \multicolumn{8}{|c|}{ Egg weight, $g$} \\
\hline Cont & 55.5 & 56.2 & 57.3 & 56.4 & 56.7 & 55.3 & 56.3 \\
\hline Trp & 54.4 & 54.5 & 53.3 & 55.3 & 54.8 & 55.1 & 55.4 \\
\hline SEM & .8 & .9 & 1.6 & .9 & .9 & 1.1 & .9 \\
\hline \multicolumn{8}{|c|}{ Egg production, g/day } \\
\hline Cont & 52.0 & 52.4 & 51.6 & 47.0 & 47.7 & 45.8 & 49.5 \\
\hline $\operatorname{Trp}$ & 50.1 & 50.5 & 46.8 & 45.1 & 44.0 & 484 & 47.7 \\
\hline SEM & 1.1 & 1.3 & 2.0 & 1.3 & 1.9 & 1.5 & 1.1 \\
\hline \multicolumn{8}{|c|}{ Feed intake, $\mathrm{g} /$ day } \\
\hline Cont & 101 & 114 & 112 & 100 & 106 & 110 & 106 \\
\hline $\operatorname{Trp}$ & 94 & 108 & 111 & 96 & 103 & 102 & 102 \\
\hline SEM & 9 & 2 & 2 & 4 & 3 & 3 & 2 \\
\hline
\end{tabular}

Mean of 12 birds. Cont: Control group, Trp: Tryptophan supplemented group.

\section{Results and Discussion}

Performance of layers such as body weight change, feed intake, egg production rate and egg weight are given in Table 1. Since grouping of the birds was made according only to the egg production rate, the average initial body weight was somewhat different between groups, being $1.73 \mathrm{~kg}$ in the control group and $1.66 \mathrm{~kg}$ in the tryptophan supplemented group. The final body weight (24 weeks after the experiment started) was 1.83 and 1.70 $\mathrm{kg}$ in the control and tryptophan supplemented groups, respectively. There were not so much differences in body weight change between groups as shown in Table 1. During 1216 week period the birds of both groups lost their body weight. This period was in May and such body weight losses sometimes occur in this season because of decreased feed intake due to a stress caused by hot and humid conditions. Feed intake was not so much different between groups, however, the tryptophan supplemented group always consumed less feed than the control group. A part of this difference might be due to the difference in body weight. According to our estimation, however, both groups consumed enough feed to meet the requirement. 
Table 2. Egg weight, albumen weight, and protein and tryptophan contents of albumen

\begin{tabular}{|c|c|c|c|c|c|c|c|c|c|c|}
\hline Week & 0 & 1 & 3 & 4 & 8 & 12 & 16 & 20 & 24 & Ave \\
\hline \multicolumn{11}{|c|}{ Egg weight, g } \\
\hline Cont & 53.7 & 55.3 & 55. 2 & 57.3 & 57.9 & 57.9 & 55.4 & 59.2 & 54.8 & 56.2 \\
\hline Trp & 55.0 & 53.9 & 54.4 & 55.2 & 56.0 & 55.8 & 54.1 & 54. 9 & 53.5 & 54.7 \\
\hline SEM & 1.8 & .8 & .9 & .9 & 1.0 & 1.0 & 1.4 & 1. 2 & 1.3 & 1.0 \\
\hline \multicolumn{11}{|c|}{ Albumen weight, $\mathrm{g}$} \\
\hline Cont & 32.1 & 32.7 & 31.7 & 32.7 & 32.9 & 32.8 & 31.8 & 34.2 & 31.8 & 32.5 \\
\hline $\operatorname{Trp}$ & 32.1 & 31.3 & 31.8 & 31.9 & 32.4 & 32.0 & 32.2 & 31.9 & 30.8 & 31.8 \\
\hline SEM & 1.0 & .7 & .7 & .8 & .8 & .8 & .9 & .8 & .9 & .8 \\
\hline \multicolumn{11}{|c|}{ Albumen weight/egg weight, $\%$} \\
\hline Cont & 59.8 & 59.0 & 57.4 & 57.3 & 57.0 & 56.5 & 57.3 & 57.8 & 57.9 & 57.8 \\
\hline Trp & 58.5 & 57.9 & 58.5 & 57.8 & 57.9 & 57.3 & 58.9 & 58.1 & 57.5 & 58.0 \\
\hline SEM & .7 & .7 & .5 & .6 & .6 & .7 & .7 & .6 & .6 & .6 \\
\hline \multicolumn{11}{|c|}{ Protein content $(\mathrm{N} \times 6.25)$ of albumen, $\%$} \\
\hline Cont & 10.0 & 8.9 & 10.6 & 10.1 & 8.8 & 10.4 & 9.9 & 9.8 & 9.7 & 9.8 \\
\hline $\operatorname{Trp}$ & 8.9 & 10.7 & 10.2 & 10.2 & 9.1 & 10.2 & 10.2 & 9.9 & 10.0 & 9.8 \\
\hline SEM & .2 & .3 & .1 & .2 & .2 & .1 & .2 & .2 & .2 & .2 \\
\hline \multicolumn{11}{|c|}{ Tryptophan content of albumen, $\mathrm{mg} / 100 \mathrm{~g}$} \\
\hline Cont & 175 & 173 & 187 & 189 & 159 & 213 & 176 & 177 & 200 & 183 \\
\hline $\operatorname{Trp}$ & 169 & 172 & 192 & 190 & 166 & 209 & 175 & 183 & 203 & 183 \\
\hline SEM & 5 & 4 & 4 & 5 & 3 & 4 & 6 & 7 & 6 & 6 \\
\hline \multicolumn{11}{|c|}{ Tryptophan/protein of albumen, $\%$} \\
\hline Cont & 1.75 & 1.93 & 1.77 & 1.84 & 1.81 & 2.05 & 1.78 & 1.81 & 2.07 & 1.86 \\
\hline $\operatorname{Trp}$ & 1. 94 & 1.86 & 1.78 & 1.85 & 1.84 & 2.05 & 1.72 & 1.85 & 2.12 & 1.88 \\
\hline SEM & .08 & .07 & .03 & .03 & .04 & .04 & .05 & .06 & .08 & .05 \\
\hline
\end{tabular}

Mean of 12 eggs. Cont: Control group, Trp: Tryptophan supplemented group.

Number of eggs laid, or egg production rate was quite comparable between groups, and egg weight was also not different between groups. Reflecting these, the daily egg production was 49.5 and $47.7 \mathrm{~g}$ in the control and tryptophan supplemented groups, respectively, and feed required for egg production (grams of feed/gram of egg produced) was calculated to be $2.14 \mathrm{~g} / \mathrm{g}$ in both groups. Again no difference was found.

Protein and tryptophan contents of egg albumen are shown in Table 2. Egg weight and albumen weight of the sample eggs were not different between groups and albumen was estimated to be $57-60 \%$ of the eggs. Although nitrogen content of egg albumen was reported to be $12-13 \%{ }^{4}$, the index of 6.25 instead of $7.69-8.33$ was used for calculation of crude protein content. The crude protein content of almumen varied from $8.9 \%$ to $10.7 \%$, and the difference between groups was sometimes significant. However, no special relation was observed, and average value was shown to be $9.8 \%$ in both groups. Tryptophan content of albumen also varied time to time, being $159-213 \mathrm{mg} / 100 \mathrm{~g}$, but no difference was observed between groups. The ratio of tryptophan to protein of albumen also varied in seasons, but again no difference was found between groups.

In conclusion, feeding of excess amount of tryptophan did not show any ill-effect on the 
performance of laying hens even when excess tryptophan was given for a long period (24 weeks). The amount of tryptophan given to the birds in this experiment was quite unusual, and the amount or rate of absorbed tryptophan and the complete fate of absorbed tryptophan in the body remain to be studied.

\title{
Summary
}

A long term (24 weeks) feeding experiment was conducted using 8.5-month-old White Leghorn pullets receiving a large dose of tryptophan. Each group consisted of 12 birds, and initial body weight was 1.66 and $1.73 \mathrm{~kg}$, and average egg production rate before experiment was $92.6 \%$ and $93.5 \%$ in experimental and control groups, respectively. A commercial laying ration was used as a controt diet, which contained $15.5 \%$ of crude protein and adequate amounts of amino acids (tryptophan $0.16 \%$ ) for layers. An experimental diet was formulated by supplementing the control diet with $0.5 \%$ of L-tryptophan, and the total tryptophan content of this diet was $0.66 \%$. Several parameters, such as body weight change, feed intake, egg production rate, egg weight, albumen weight, protein/albumen ratio, tryptophan content of albumen, were measured to compare the normal and excess dosages of tryptophan. The result indicates that a large dose of tryptophan to the laying hens did not show any ill-effect even in a long period of feeding.

The authors are grateful to the Ajinomoto Co. Ltd. for the support of this work.

\section{References}

1) TASAKI, I. (1983) Influence of tryptophan deficiency and excess on egg production in laying pullets: Japan. Poult. Sci., 20: 103-109.

2) Blackburn, S. (1968) Amino Acid Determination: Mercel Dekker, N. Y., 13-22.

3) Spies, J. R. and D. C. Chambers (1984) Chemical determination of tryptophan: Anal. Chem., 20: 30-39.

4) Harvey, D. (1956) Tables of the Amino Acids in Foods and Feedingstuffs: Commonwealth Bureau of Animal Nutrition Tech. Comm., 19: 7-8, Slough, Scotland.

\section{産卵鶏に対する過剩トリプトファンの長期給与試験}

\author{
田先威和夫・朝 倉 幸 孜・小宮美智子
}

们古屋大学: 農学部名古屋市 464

\footnotetext{
8.5 か月齢の门色レグホーン若雌を用い, 大量のトリ ブトファンを 24 週間にわたり給与し，その影響を調柏 した。対照区, 試験区とも各 12 羽ずつ用い, 前者には CP 15.5\%の市販産卵用飼料を与之，後者には防販䣳料 に Lートリフトファンを0.5\%添加給与した。な拈市販 飼料のトリブトファン含量を測定した結果は $0.16 \%$ で

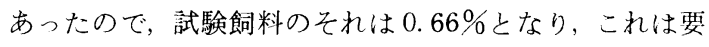
求量の $655 \%$ に相当する. 試験前の平均産卵率は, 試験
} 区で $92.6 \%$ ，対照区で 93.5\%であり，闾始時体重はそ
れぞれ $1.66 \mathrm{~kg}$ 拈よび $1.73 \mathrm{~kg}$ であった。

24 週間にわたり体重の変化, 飼料掑取量, 産卵率, 卵 重, 卵古重, 卵古中のトリフトファン含量などを測定比 較したが，いずれも期閒によるばらつきはあるものの， 両区間には全く差が認められなかった。以上の結果よ り，かなり多量のトリフトファンを長期間にわたって産 卵䳕に給与しても産卵に悪影響を与えることはないと考 えられた。

（家㜄会誌，22，23～26，1985） 